\section{Comparing a Smartphone Irrigation Scheduling Application with Water Balance and Soil Moisture-based Irrigation Methods: Part II-Plasticulture-grown Watermelon}

\author{
Luke Miller $^{1}$, George Vellidis ${ }^{2}$, and Timothy Coolong ${ }^{1,3}$
}

ADDITIONAL INDEX wORDs. Citrullus lanatus drip irrigation, water use efficiency, evapotranspiration, plastic mulch

SumMARY. A new smartphone irrigation scheduling application (VegApp) was compared with current irrigation scheduling recommendations and an automated soil moisture sensor (SMS)-based irrigation system in southern Georgia during Spring 2016 and 2017. Plants were grown using plastic mulch and drip irrigation following standard production practices for watermelon (Citrullus lanatus) in Georgia. The VegApp irrigation regime was based on evapotranspiration $\left(\mathrm{ET}_{\mathrm{o}}\right)$ values calculated from real-time data collected from a nearby weather station. Current irrigation scheduling recommendations use a water balance (WB) method. The WB method uses historic averages for determining $\mathrm{ET}_{\mathrm{o}}$ rates for the season. Water applied, soil water tension at 6-, 10-, and 14-inch depths, yield, and fruit quality were evaluated. In 2016, the SMS-based irrigation plots applied the least water. In 2017, the lowest amount of water was applied to plants grown using the VegApp. Total marketable yields were not significantly affected by irrigation regime. However, 45-count fruit yields were affected by irrigation in 2017. Plants grown using SMS-based irrigation had significantly higher yields of 45-count fruit than those grown using the WB method. Irrigation water use efficiency (IWUE) was affected by irrigation treatment and year. The SMS-irrigated plants had the greatest IWUE, although it was not significantly different from plants grown using the VegApp irrigation program. Internal quality parameters including, firmness, hollow heart, and total soluble solids (TSS) were not significantly affected by irrigation scheduling during the study. The results suggest that overall water applications may be reduced and yields maintained when using VegApp compared with traditional WB methods of irrigation scheduling.

G eorgia is a top watermelon producer in the United States with $\approx 20,000$ acres planted annually valued at $\$ 130$ million (Wolfe and Stubbs, 2016). Most watermelon production is in the southern portion of the state where soils are sandy and well drained. Although watermelon are relatively drought tolerant, it is estimated that at least 16-24 inches of water are required to produce adequate yields during a typical production season (Allen et al., 1998). Watermelon roots may grow up to $1.5 \mathrm{~m}$ deep; however, most roots are found in the top $25 \mathrm{~cm}$ of soil (Miller et al., 2014). Critical periods of water management for watermelon are during early bloom and fruit development (Shukla et al.,

${ }^{1}$ Department of Horticulture, University of Georgia, 2360 Rainwater Road, Tifton, GA 31793

${ }^{2}$ Crop and Soil Sciences Department, University of Georgia, 2360 Rainwater Road, Tifton, GA 31793

${ }^{3}$ Corresponding author. E-mail: tcoolong@uga.edu.

https://doi.org/10.21273/HORTTECH04014-18
2013). Incidence of foliar diseases including anthracnose (Colletotrichum orbiculare) or phytophthora fruit rot (Phytophthora capsici) may be exacerbated by excessive irrigation (Hausbeck and Lamour, 2004; Hord and Ristaino, 1992; Zitter et al.,
1996). Irrigation is typically limited near harvest as excess water has been reported to negatively affect watermelon internal quality (Shukla et al., 2013). Fruit TSS content is often used as an indicator of total sugar concentration in watermelon and has been negatively correlated with irrigation volume late in fruit development (Rouphael et al., 2008). Overwatering during fruit development can also increase hollow heart incidence (Proietti et al., 2008).

Current recommendations for drip-irrigated watermelon in Georgia and Florida are based on variations of the WB method (Harrison, 2009). The WB method determines irrigation requirements by calculating crop water use based on historic $\mathrm{ET}_{\mathrm{O}}$ values for a region adjusted with a crop coefficient $\left(\mathrm{K}_{\mathrm{c}}\right)$ (Allen et al., 1998). Current recommendations use a range of $\mathrm{K}_{\mathrm{c}}$ associated with five stages of watermelon maturity correlated to a days-after-transplanting (DAT) model (Dukes et al., 2015). Irrigation based on historic $\mathrm{ET}_{\mathrm{o}}$ values may be subject to inaccuracies due to changes in annual weather patterns (Bonachela et al., 2006). Daily $\mathrm{ET}_{\mathrm{o}}$ values may deviate from historical averages by up to $25 \%$ depending on the weather conditions experienced (Dukes et al., 2015). The WB method can allow growers to estimate overall crop water requirements; however, accuracy is limited.

Soil moisture status can also be used to schedule irrigation. Soil moisture sensor-based irrigation may use tensiometers, granular matrix, or resistance-based sensors to

\begin{tabular}{llll}
\hline $\begin{array}{l}\text { Units } \\
\text { To convert U.S. to SI, } \\
\text { multiply by }\end{array}$ & U.S. unit & SI unit & $\begin{array}{l}\text { To convert SI to U.S., } \\
\text { multiply by }\end{array}$ \\
\hline 0.4047 & acre $(\mathrm{s})$ & $\mathrm{ha}$ & $2.471 \mathrm{l}$ \\
$\mathrm{l}$ & $\mathrm{cbar}$ & $\mathrm{kPa}$ & $\mathrm{l}$ \\
29.5735 & $\mathrm{fl} \mathrm{oz}$ & $\mathrm{mL}$ & 0.0338 \\
0.3048 & $\mathrm{ft}$ & $\mathrm{m}$ & 3.2808 \\
0.1242 & $\mathrm{gal} / 100 \mathrm{ft}$ & $\mathrm{L} \cdot \mathrm{m}^{-1}$ & 8.0520 \\
9.3540 & gal/acre & $\mathrm{L} \cdot \mathrm{ha}^{-1}$ & 0.1069 \\
2.54 & inch $(\mathrm{es})$ & $\mathrm{cm}$ & 0.3937 \\
25.4 & inch(es) & $\mathrm{mm}$ & 0.0394 \\
453.5934 & $\mathrm{lb}$ & $\mathrm{g}$ & 0.0022 \\
0.4536 & $\mathrm{lb}$ & $\mathrm{kg}$ & 2.2046 \\
1.1209 & $\mathrm{lb} / \mathrm{acre}$ & $\mathrm{kg} \cdot \mathrm{ha}^{-1}$ & 0.8922 \\
0.1198 & $\mathrm{lb} / \mathrm{gal}$ & $\mathrm{kg} \cdot \mathrm{L}^{-1}$ & 8.3454 \\
4.4482 & $\mathrm{lbf}$ & $\mathrm{N}$ & 0.2248 \\
0.0254 & $\mathrm{mil}$ & $\mathrm{mm}$ & 39.3701 \\
1 & $\mathrm{ppm}$ & $\mathrm{mg} \cdot \mathrm{L}^{-1}$ & 1 \\
6.8948 & $\mathrm{psi}$ & $\mathrm{kPa}$ & 0.1450 \\
$\left({ }^{\circ} \mathrm{F}-32\right) \div 1.8$ & ${ }^{\circ} \mathrm{F}$ & ${ }^{\circ} \mathrm{C}$ & $\left({ }^{\circ} \mathrm{C} \times 1.8\right)+32$ \\
& & &
\end{tabular}


determine irrigation thresholds (Cardenas-Lailhacar et al., 2010; Munoz-Carpena et al., 2005). Although SMS-based irrigation has been reported to be more efficient than a time or WB-based system (Munoz-Carpena et al., 2005; Zotarelli et al., 2009), sensor readings may be affected by soil type and depth of drip tubing (Coolong, 2016; Dabach et al., 2015).

Recently, smartphone applications have been developed that schedule irrigation using real-time weather data to calculate $\mathrm{ET}_{\mathrm{o}}$ [Smartirrigation App (University of Florida, 2012)]. These irrigation scheduling applications use data generated by nearby weather stations in Georgia or Florida to schedule irrigation. Migliaccio et al. (2016) reported up to a $37 \%$ reduction in water use for growers using an irrigation scheduling application for citrus (Citrus sp.) in southern Florida in comparison to using the WB method. Using an irrigation scheduling application for cotton (Gossypium hirsutum) resulted in a reduction in irrigation water use of $40 \%$ to $75 \%$ in Georgia, while maintaining yields (Vellidis et al., 2015).

The VegApp represents a step forward in irrigation scheduling that is accessible to growers. It is free to download, user friendly, and may be more efficient than WB-based irrigation (De Pascale et al., 2011). The VegApp may avoid some of the technical challenges associated with SMS-based irrigation. However, the VegApp is relatively new and has yet to be thoroughly used by growers in the region. We hypothesize that the VegApp may use less water than WB-based irrigation methods, while maintaining similar yields. Therefore, the objectives of this study were to compare water usage, yield, and quality of watermelon grown using the VegApp with current recommendations and a SMS-based irrigation regime.

\section{Materials and methods}

This study was conducted at The University of Georgia, Tifton Vegetable Park in Tifton, GA (lat. $31^{\circ} 5^{\prime} \mathrm{N}$, long. $83^{\circ} 5^{\prime} \mathrm{W}$ ), in 2016 and 2017. The soil at the site is a Tifton loamy sand series ( $0 \%$ to $2 \%$ slope). Seedless 'Melody' (Syngenta Seeds, Woodland, CA) watermelon with the pollenizer 'Sp6' (Syngenta Seeds) were grown in the greenhouse for 6 weeks using a peat-based soilless mix (ProMix BX; Premier Tech, Rivieredu-Loup, QC, Canada) in 200-cell trays (Speedling, Ruskin, FL). Seeded trays were placed in a germination chamber $\left(85\right.$ to $90{ }^{\circ} \mathrm{F}, 90 \%$ relative humidity) for $48 \mathrm{~h}$ and then moved to a greenhouse for production. Temperature set points of $84 / 68^{\circ} \mathrm{F}$ (day/night) were used. Plants were watered twice daily as needed and fertilized three times per week after germination with a $150 \mathrm{mg} \cdot \mathrm{L}^{-1}$ nitrogen $(\mathrm{N})$ solution $(20 \mathrm{~N}-4.4 \mathrm{P}-$ 16.6K; Scotts, Marysville, OH).

Soils were fumigated with 194 $\mathrm{lb} /$ acre chloropicrin and $129 \mathrm{lb} /$ acre 1,3-dichloropropene (Pic-Chlor 60; TriEst Ag Group, Tifton, GA) when plastic was laid. Irrigation was supplied with a single line of drip-irrigation tubing [12 inches emitter spacing, $0.50 \mathrm{gal} / \mathrm{min}$ per $100 \mathrm{ft}$ at $10 \mathrm{psi}$, (Chapin DLX; Jain USA, Haines City, FL)] placed at a depth of 1-2 inches. Fumigation, plastic laying, and preplant fertility were carried out using a raised-bed plastic mulch layer with attached fumigation system and fertilizer hopper (SuperBedder; Kennco Manufacturing, Ruskin, FL). Preplant fertility consisted of $50 \mathrm{lb} / \mathrm{acre} \mathrm{N}[5.0 \mathrm{~N}-4.3 \mathrm{P}-14.5 \mathrm{~K}$ (Rainbow Plant Food; Agrium, Tifton, GA)] placed in the row immediately before laying plastic mulch. Beds were 6 inches tall by 32 inches wide and covered with a 1.1-milthick impermeable film plastic mulch (Vaporsafe RM, TIF, 60 inches; Raven Industries, Sioux Falls, SD). An herbicide mixture containing the active ingredients $0.12 \mathrm{lb} /$ acre flumioxazin (Chateau; Valent USA, Walnut Creek, CA), 0.7 lb/acre $S$-metaloachlor (Dual Magnum; Syngenta, Greensboro, NC), 0.38 lb/acre ethalfluralin (Curbit 3 EC; Loveland Products, Loveland, $\mathrm{CO})$, and $0.84 \mathrm{lb} /$ acre glyphosate (Round Up WeatherMax; Monsanto, St. Louis, MO) was applied between rows with a shielded sprayer $\approx 2$ weeks before transplanting.

Seedlings were transplanted by hand on 28 Mar. and 13 Apr. in 2016 and 2017, respectively. Plots consisted of two rows of plants spaced $6 \mathrm{ft}$ apart on center with 42 -inch inrow spacing (2074 plants/acre). Plots contained 30 and 20 plants each in 2016 and 2017, respectively.
Pollenizer plants, 'Sp6', were planted equidistant between every third and fourth plants in a row. There were four replications of each irrigation treatment and the study was arranged in a randomized complete block design. Plants were watered equally for $\approx 3$ and 4 weeks after transplanting in 2016 and 2017, respectively, at which time irrigation treatments were implemented. Plants received an additional 130 and $117 \mathrm{lb} /$ acre $\mathrm{N}$ in 2016 and 2017 growing seasons, respectively. Fertigation was begun $10 \mathrm{~d}$ after planting through applications of $13 \mathrm{lb} \mathrm{N} /$ acre $[7 \mathrm{~N}-0 \mathrm{P}-5.8 \mathrm{~K}$ (Big Bend Agri-Services, Cairo, GA)] for season totals of 180 and $167 \mathrm{lb} /$ acre $\mathrm{N}$ in 2016 and 2017, respectively. Fungicides and insecticides were applied weekly according to commercial recommendations for watermelon grown in Georgia (Horton, 2016).

The VegApp calculated crop evapotranspiration $\left(\mathrm{ET}_{\mathrm{c}}\right)$ from weather data collected by the University of Georgia Weather Network weather station in Tifton. These data were used to calculate $\mathrm{ET}_{\mathrm{o}}$ from air temperature, solar radiation, wind speed, and relative humidity using the PenmanMonteith equation (Migliaccio et al., 2016). Then $\mathrm{ET}_{\mathrm{O}}$ was adjusted using a $\mathrm{K}_{\mathrm{c}}$ based on a DAT model of crop maturity for drip-irrigated watermelon grown on plastic mulch (Dukes et al., 2015). Additional model variables entered into the VegApp included row spacing, irrigation rate (gallons per $100 \mathrm{ft} / \mathrm{h}$ ), irrigation system efficiency, and planting date. The VegApp then calculated an average $\mathrm{ET}_{\mathrm{O}}$ using data from the previous $5 \mathrm{~d}$ and estimated $\mathrm{ET}_{\mathrm{c}}$ based on the following equation: $\mathrm{ET}_{\mathrm{c}}=\mathrm{ET}_{\mathrm{o}} \times \mathrm{K}_{\mathrm{c}}$. Irrigation run times were then calculated using the previously entered row spacing, flow rate, and irrigation system efficiency. The VegApp differs from other irrigation scheduling applications in that it does not integrate rainfall into the irrigation schedule and it does not account for soil type (Migliaccio et al., 2016). Irrigation run times were divided into two daily irrigation events.

Irrigation schedules for WBmanaged plots were calculated based on estimated crop water demand using historic $\mathrm{ET}_{\mathrm{o}}$ rates adjusted with a $\mathrm{K}_{\mathrm{c}}$ for watermelon. Historic $\mathrm{ET}_{\mathrm{o}}$ for each month was estimated from 
a 10-year monthly average of measured $\mathrm{ET}_{\mathrm{o}}$ rates for several geographical regions of Florida (Dukes et al., 2015 ). The $\mathrm{K}_{\mathrm{c}}$ used in this study were for plasticulture-grown watermelon and were as follows: 0-21 DAT = $0.3,21-42$ DAT $=0.5,42-70 \mathrm{DAT}$ $=0.7,70-91$ DAT $=0.9$, and 91-105 $\mathrm{DAT}=0.8$ (Dukes et al., 2015). Because of proximity to the research site, historic $\mathrm{ET}_{\mathrm{o}}$ rates attributed to northwest Florida were used. Total $\mathrm{ET}_{\mathrm{c}}$ was then divided by irrigation system efficiency, which was estimated to be $95 \%$ for all treatments in this study, to determine total irrigation volume. Drip-irrigation flow rate and row spacing were then used to calculate the time required to apply the desired volume of water. As with the VegApp, required irrigation run times were divided into two equal daily irrigation events for WB-based methods. Rainfall amounts were not included in irrigation calculations in WB- or VegApp-based treatments.

The SMS-based irrigation regime was automated using pairedswitching tensiometers (model RA 6 inches; Irrometer, Riverside, CA) (Coolong, 2016; Coolong et al., 2011). In brief, one tensiometer functioned to turn on irrigation at the set point reflecting a higher (drier) soil moisture tension whereas the other turned it off at the set point indicating the lower (wetter) soil moisture tension. Tensiometers were placed $\approx 6$ inches from a drip emitter and a watermelon plant at a depth of 6 inches from the bed surface. Irrigation treatments had set points of on/ off: $-18 /-10 \mathrm{kPa}$, which were estimated to reflect $75 \%$ of plant available water and field capacity, respectively, for the soil at the research site. Water use in all treatments was recorded weekly using mechanical flow meters (DLJSJ50 Water Meter; Daniel L Jerman Co., Hackensack, NJ). Plots receiving SMS-based irrigation were controlled independently and each plot had a pair of tensiometers.

Soil moisture probes (Watermark, Irrometer) were used in combination with a smart sensor array (SSA). The SSA consists of smart sensor nodes and gateway sensor nodes, which consist of a circuit board, a radio frequency transmitter, as well as soil moisture and temperature sensors (Vellidis et al., 2008). Environmental data from the array was recorded every $5 \mathrm{~min}$ and transmitted to a server hourly (Vellidis et al., 2013). Probes were placed at 6-, 10-, and 14-inch depths in each plot to monitor soil moisture levels. Sensors were placed into holes and then sealed with mud slurry made from soil removed from the hole. Sensors were placed $\approx 6$ inches from drip-irrigation emitters in each plot.

Watermelons were harvested three times during 2016 and 2017. Harvest periods ranged from 29 June to 13 July in 2016 and from 27 June to 12 July in 2017. All fruit were graded based on U.S. Department of Agriculture grade standards for U.S. No. I watermelons (USDA, 2006) and industry standards for size. All fruit were weighed individually and categorized into 60-, 45-, 36-, and 30-count fruit for those watermelons weighing 9.0-13.5, $13.6-17.5,17.6-21.4$, and $\geq 21.5 \mathrm{lb}$, respectively.

Watermelon internal quality parameters were measured on five randomly selected, fully ripened fruit from each treatment and replication during each harvest. Firmness, TSS, and hollow heart incidence and severity were determined by slicing watermelon longitudinally in half. Fruit TSS were measured on a composite sample of five fruit. A melon baller ( 5 $\mathrm{mL}$ ) was used to remove flesh from the center of each fruit, which was then crushed using a handheld lemon press. About $0.5 \mathrm{~mL}$ of juice was then applied to a handheld a refractometer for measurement of TSS. Flesh firmness was measured using a handheld firmness tester with an $11-\mathrm{mm}$ probe (FDK 160; Wagner Instruments, Greenwich, CT). The probe was inserted twice near the center of each half of a fruit for a total of four firmness measurements per fruit. Hollow heart incidence was graded on a scale of 0 to 5 , where 0 corresponded to no presence of hollow heart and 5 was a severe incidence of hollow heart (Coolong, 2017).

Foliar macronutrient concentrations were determined from plant material collected $\approx 2$ weeks before first harvest. One of the newest fully expanded leaves from each of 15 and 10 representative plants in the center of each plot in 2016 and 2017, respectively, were sampled and combined in paper bags. Each sample was oven dried at $50{ }^{\circ} \mathrm{C}$ for a minimum of
$10 \mathrm{~d}$. Samples were analyzed by a commercial laboratory (Waters Agricultural Laboratory, Camilla, GA) for nutrient content.

Midday leaf water potential $\left(\psi_{\mathrm{L}}\right)$ measurements were conducted on 4 and 15 June 2016 and 15,19 , and 26 June 2017, respectively. Measurements of $\psi_{\mathrm{L}}$ were conducted within one and half hours of solar noon in both years of the study. Plant $\psi_{\mathrm{L}}$ was measured using a pressure chamber (model 615; PMS Instrument Co., Albany, OR) using fully expanded leaves exposed to full sunlight from plants near the center of each plot. Excised leaves were wrapped in polyethylene bags and measured within 1 min of sampling.

Data were subjected to the general linear model (GLM) procedure and mean separation using Tukey's honest significant difference test $(P<0.05)$ with SAS statistical software (version 9.3; SAS Institute, Cary, NC).

\section{Results and discussion}

Total season $\mathrm{ET}_{\mathrm{c}}$ was greater in 2016 than 2017, which was due to a higher $\mathrm{ET}_{\mathrm{c}}$ in May and June of 2016 compared with 2017 and a shorter overall trial period in 2017 (Table 1). Average daily high air temperatures in June 2016 were $90.2{ }^{\circ} \mathrm{F}$ compared with $85.8{ }^{\circ} \mathrm{F}$ for the same period in 2017. The 2017 study period had 2.44 inches more rainfall than the 2016 study (Table 1). A majority of the rainfall from June 2016 occurred during a single event on 5 June (data not shown). Little rainfall was received during the remainder of June and July 2016, when plant canopies were largest and $\mathrm{ET}_{\mathrm{c}}$ was most affected by weather conditions.

During the 2016 study, the WB method of irrigation applied $323,390 \mathrm{gal} /$ acre of water and averaged $3760 \mathrm{gal} /$ acre per day (Table 2 ). In $2016,309,130 \mathrm{gal} /$ acre of water was applied to plants using the VegApp resulting in daily average applications of $3590 \mathrm{gal} /$ acre. The SMS-based irrigation method applied $213,540 \mathrm{gal} /$ acre for the season, which averaged $2480 \mathrm{gal} /$ acre per day. The SMS irrigation method used the least amount of water in 2016, which is similar to results obtained in other studies evaluating the impact of tensiometers on irrigation scheduling in other vegetable crops (Dukes et al., 2003; Smajstrla and Locascio, 
Table 1. Accumulated rainfall, estimated crop evapotranspiration $\left(\mathrm{ET}_{\mathrm{c}}\right)$, reference evapotranspiration $\left(\mathrm{ET}_{\mathrm{o}}\right)$, and the average daily maximum $\left(T_{\max }\right)$ and minimum $\left(T_{\min }\right)$ temperatures during the treatment period for watermelon grown at Tifton, $G A$, in 2016 and 2017.

\begin{tabular}{|c|c|c|c|c|c|}
\hline & $\underline{\text { Rainfall }}$ & $\mathrm{ET}_{\mathrm{c}}^{\mathrm{z}}$ & $\mathrm{ET}_{\mathrm{o}}$ & $\mathbf{T}_{\max }$ & $\mathbf{T}_{\min }$ \\
\hline & & nches) & & \multicolumn{2}{|c|}{$\left({ }^{\circ} \mathrm{F}\right)^{\mathrm{y}}$} \\
\hline \multicolumn{6}{|l|}{2016} \\
\hline May & 1.45 & 3.74 & 5.81 & 83.7 & 61.3 \\
\hline June & 3.94 & 5.33 & 6.20 & 90.2 & 69.6 \\
\hline 1-13 July & 0.09 & 2.30 & 2.88 & 91.6 & 72.3 \\
\hline 14-31 May & 1.21 & 1.34 & 2.68 & 86.5 & 65.6 \\
\hline June & 5.11 & 3.36 & 4.58 & 85.8 & 68.8 \\
\hline 1-12 July & 1.63 & 2.01 & 2.51 & 91.3 & 72.3 \\
\hline Total & 7.95 & 6.71 & 9.77 & 87.2 & 68.6 \\
\hline
\end{tabular}

${ }^{\mathrm{z}} \mathrm{ET}_{\mathrm{c}}=\mathrm{ET}_{\mathrm{o}} \times$ crop coefficient $\left(\mathrm{K}_{\mathrm{c}}\right) ; \mathrm{l}$ inch $=2.54 \mathrm{~cm}$.

${ }^{\mathrm{y}}\left({ }^{\circ} \mathrm{F}-32\right) \div 1.8={ }^{\circ} \mathrm{C}$.

Table 2. Irrigation volume and daily water applied for watermelon grown using a smartphone vegetable irrigation-scheduling application (VegApp), water balance (WB), and soil moisture sensor (SMS) methods at Tifton, GA, in 2016 and 2017.

\begin{tabular}{|c|c|c|}
\hline Irrigation treatment & $\begin{array}{c}\text { Irrigation vol } \\
(\text { gal/acre })^{\mathrm{z}}\end{array}$ & $\begin{array}{c}\text { Daily water applied } \\
\text { (gal/acre per day) }\end{array}$ \\
\hline & \multicolumn{2}{|c|}{2016} \\
\hline VegApp & 309,130 & 3,590 \\
\hline WB & 323,290 & 3,760 \\
\hline \multirow[t]{2}{*}{ SMS } & 213,540 & 2,480 \\
\hline & \multicolumn{2}{|c|}{2017} \\
\hline VegApp & 153,720 & 2,605 \\
\hline WB & 221,000 & 3,745 \\
\hline SMS & 173,120 & 2,934 \\
\hline
\end{tabular}

${ }^{\mathrm{z}} 1$ gal $/$ acre $=9.3540 \mathrm{~L} \cdot \mathrm{ha}^{-1}$.

1990). Irrigation volumes in 2017 were lower than 2016 for all treatments. This was the result of shorter study duration in 2017 compared with 2016 and a lower $\mathrm{ET}_{\mathrm{c}}$. In 2017, The WB irrigation method applied 221,000 gal/acre irrigation water for the season resulting in an average of $3745 \mathrm{gal} /$ acre per day. The VegApp and SMS irrigation treatments applied 153,720 and 173,120 $\mathrm{gal} / \mathrm{acre}$ water, respectively, in 2017. This resulted in an average daily water application of 2605 and $2934 \mathrm{gal} /$ acre for the VegApp and SMS plots, respectively. The daily irrigation volumes in the $\mathrm{WB}$ treatments were similar in 2016 and 2017, although total season volumes were lower in 2017 compared with 2016. This was likely the result of discontinuing irrigation in the VegApp and WB treatments for several days in June and July 2017 because of significant rain events resulting in saturated soils surrounding the plots. Irrigation was discontinued to reduce the potential impact of disease. Irrigation in the SMS-based treatments remained on to account for tensiometers detecting increased soil moisture and not starting irrigation unless soil conditions became appropriately dry. The relative increase in water usage among SMS plots compared with the others in 2017 may be the result of some irrigation occurring during this period and subtle differences in tensiometer placement relative to root growth in the plant beds. Currently, the contribution of rainfall for vegetable crops has not been incorporated into the VegApp due to limited information regarding the impact of rainfall on soil moisture levels under plastic mulches and spatial variability of rain events (Migliaccio et al., 2016). The increased daily water usage for the SMS-based irrigation in 2017 suggests that despite saturated soils surrounding plots, soil moisture levels adjacent to the tensiometers did not change significantly because of rainfall.

In 2017, the VegApp accounted more appropriately for lower levels of $\mathrm{ET}_{\mathrm{c}}$ in late May and June compared with 2016 , applying $27 \%$ less water on a daily basis compared with 2016 . If the period of time when irrigation was discontinued in 2017 is accounted for, the volume of water applied in the VegApp treatment was similar to estimated $\mathrm{ET}_{\mathrm{c}}$ for the study period. In 2016 , estimated $\mathrm{ET}_{\mathrm{c}}$ was $\approx 8.9 \%$ greater than irrigation water applied in the VegApp treatments (Tables 1 and 2). The VegApp uses $\mathrm{ET}_{\mathrm{c}}$ from the previous $5 \mathrm{~d}$ to schedule irrigation for the proceeding week. Although more efficient than a historic $\mathrm{ET}_{\mathrm{o}}$ method some error is expected when using the VegApp if rapid changes in weather conditions occur. When averaged over the 2 years of the study, the VegApp- and SMS-based irrigation regimes applied $15 \%$ and $29 \%$ less water, respectively, than the $\mathrm{WB}$ method. The cumulative water application data suggest that the VegApp was more conservative in scheduling water than the current recommended WB method. Several studies have reported improved irrigation efficiencies using SMS-based or real-time $\mathrm{ET}_{\mathrm{c}}$ data compared with historic ET $_{\mathrm{o}}$-based methods (De Pascale et al., 2011; Munoz-Carpena and Dukes, 2017).

There were significant treatment by year by depth by month interactions $(\mathrm{F}=53.6, P \leq 0.01)$ for soil moisture levels (Table 3). In Apr. 
Table 3. Soil moisture tension at depths of 6, 10, and 14 inches in watermelon irrigated using smartphone vegetable irrigation scheduling application (VegApp), water balance (WB), and soil moisture sensor (SMS) methods at Tifton, GA, in 2016 and 2017.

\begin{tabular}{|c|c|c|c|c|c|c|c|c|}
\hline \multirow{3}{*}{$\begin{array}{l}\text { Depth } \\
\text { (inches) }^{z}\end{array}$} & \multirow[b]{3}{*}{ Treatment } & \multicolumn{7}{|c|}{ Soil moisture tension $(\mathrm{cbar})^{\mathrm{z}}$} \\
\hline & & \multicolumn{4}{|c|}{2016} & \multicolumn{3}{|c|}{2017} \\
\hline & & Apr. & May & June & July & May & June & July \\
\hline & WB & $0.00 \mathrm{a}$ & $5.17 \mathrm{~b}$ & $0.22 \mathrm{a}$ & $0.09 \mathrm{a}$ & $3.14 \mathrm{a}$ & $3.58 \mathrm{a}$ & $1.64 \mathrm{a}$ \\
\hline & SMS & $0.19 \mathrm{a}$ & $4.22 \mathrm{~b}$ & $3.23 \mathrm{~b}$ & $5.82 \mathrm{~b}$ & $14.66 \mathrm{~b}$ & $11.87 \mathrm{~b}$ & $41.82 \mathrm{c}$ \\
\hline 10 & VegApp & $0.16 \mathrm{a}$ & $0.51 \mathrm{a}$ & $0.14 \mathrm{a}$ & $0.00 \mathrm{a}$ & $1.15 \mathrm{~b}$ & $6.33 \mathrm{~b}$ & $1.26 \mathrm{a}$ \\
\hline \multirow[t]{3}{*}{14} & VegApp & $0.00 \mathrm{a}$ & $0.85 \mathrm{a}$ & $0.71 \mathrm{a}$ & $0.00 \mathrm{a}$ & $0.87 \mathrm{a}$ & $7.29 \mathrm{~b}$ & $5.08 \mathrm{~b}$ \\
\hline & $\mathrm{WB}$ & $0.00 \mathrm{a}$ & $8.14 \mathrm{c}$ & $2.55 \mathrm{~b}$ & $1.35 \mathrm{a}$ & $0.33 \mathrm{a}$ & $0.61 \mathrm{a}$ & $0.03 \mathrm{a}$ \\
\hline & SMS & $0.00 \mathrm{a}$ & $5.03 \mathrm{~b}$ & $8.33 \mathrm{c}$ & $10.50 \mathrm{~b}$ & $11.11 \mathrm{~b}$ & $15.61 \mathrm{c}$ & $58.23 \mathrm{c}$ \\
\hline
\end{tabular}

${ }^{\mathrm{z}} \mathrm{l}$ inch $=2.54 \mathrm{~cm} ; \mathrm{l} \mathrm{cbar}=1 \mathrm{kPa}$.

${ }^{\mathrm{y}}$ Values in the same column and year followed by the same letter are not significantly different at $P \leq 0.05$ according to Tukey's honest significant difference test.

2016, there was little plant canopy and soil moisture levels remained high at all depths (Table 3). In May 2016, VegApp-treated plots retained the greatest soil moisture at all depths, whereas WB- and SMS-based plots had similar moisture levels at 6- and 10-inch depths. At a depth of 14 inches, the WB-based plots had a greater moisture tension than the SMS-based plots. In June and July 2016, VegApp- and WB-managed plots had similar soil moisture levels at 6- and 10-inch depths, whereas SMS-managed plots had significantly higher soil moisture tension values. This may be because of the placement of the porous tip of the tensiometers in the SMS treatments, which can result in maintaining greater water demand at shallower depths compared with the VegApp (Marouelli and Silva, 2007). Soil moisture tension values were above or near field capacity for all treatments and depths in 2016, suggesting that plants were not subjected to drought stress.

In 2017, SMS plots had significantly higher soil moisture tension values than the VegApp- and WBmanaged plots for most depths and sampling periods (Table 3 ). The differences were relatively small in May and June, but in July, the differences in soil moisture tension between SMS-managed plots and other treatments were significant. Midday leaf water potential readings recorded in June, in both study years were not significantly different among treatments and were low overall (data not shown). This suggests that the increased soil moisture tensions in the SMS-based treatment were not reflected in plant moisture status during the June sampling period. During May and June 2017, the SMS-based plots maintained soil moisture tensions within the $-18 /-10 \mathrm{kPa}$ on/off range of the tensiometers. The increase in recorded soil moisture tension in early July may have been due to differences in root growth of plants near the smart sensor probes compared with tensiometers. The VegApp-managed plots received 11\% less water than SMS-based plots in 2017, while maintaining lower soil moisture tensions. This suggests that volume of water applied may not have been the primary reason for the relatively higher moisture tensions in the SMS-managed plots.

There was a significant year by treatment interaction for yield of 45 -count fruit $(\mathrm{F}=9.5, P \leq 0.05)$ (Table 4). There were no treatment-byyear interactions for total marketable yield or other size categories. When main effects were analyzed, there were no treatment effects on yield. Total marketable yields ranged from 43,390 $\mathrm{lb} /$ acre $(\mathrm{WB})$ to $49,680 \mathrm{lb} /$ acre (VegApp) in 2016 and 50,280 lb/acre (VegApp) to $59,540 \mathrm{lb} /$ acre $(\mathrm{WB})$ in 2017. The yield of 60-count fruit was not affected by treatment in either season. Yield of 45-count fruit in WB-managed plots was significantly lower than in VegApp and SMS-managed plots in 2017. Year significantly affected yields of 36 $(\mathrm{F}=22.2, P \leq 0.05)$-count fruit (data not shown). Yield of 36-count fruit significantly decreased in $2017 \mathrm{com}$ pared with 2016. This decrease in 36-count yield was offset by increased yields of 45-count fruit, resulting in no difference in total yields. The yields of 30-count fruit, which are less desirable than other sizes for wholesale markets, represented the least amount of fruit harvested.

The availability and timing of watermelon harvest can affect the price growers receive for their product in Georgia. Typically prices are the highest in early June and fall until early July at which time the harvest moves to another location in the United States. The impact of irrigation on harvest timing is important. There was a significant year-by treatment interaction $(\mathrm{F}=4.35, P \leq 0.05)$ for first-harvest yield. In 2016, SMSgrown plants had a significantly lower first harvest yield than VegApp-and WB-based treatments (Table 4). Despite maintaining a relatively low soil moisture tension, the reduction in water applied in the SMS-grown plants in the warmer and drier 2016 compared with the other treatments may have resulted in a delay in fruit maturation. There were no differences in first-harvest yields among treatments in 2017.

Average fruit weight was unaffected by treatment in either year. In 2016, average fruit weight ranged from 14.8 to $15.5 \mathrm{lb} /$ fruit in the SMS and WB-grown fruit, respectively. In 2017, average fruit weights ranged from 15.5 to $16.3 \mathrm{lb} /$ fruit in the VegApp- and WB-grown plants, respectively. Total marketable yields were comparable with those expected from commercial watermelon fields in Georgia (Boyhan et al., 2017). Our 


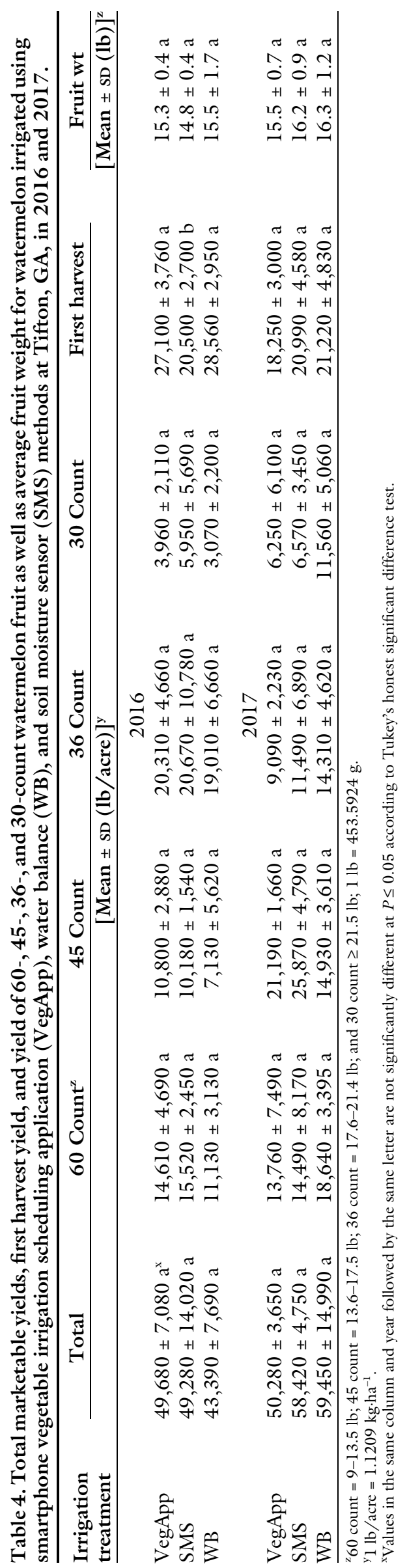

results suggest that the VegApp produced similar yields to recommended grower practices for watermelon production in Georgia.

There were no significant yearby treatment interactions for IWUE. However, treatment $(\mathrm{F}=7.2, P \leq$ $0.05)$ and year $(\mathrm{F}=34.1, P \leq 0.05)$ individually affected IWUE (Table 5 ). The SMS-based treatment had the highest numerical IWUE, although it was not significantly different from VegApp-grown plants. Plants irrigated with the WB method had a significantly lower IWUE than SMSirrigated plants. In 2016, IWUE ranged from $0.20 \mathrm{lb} / \mathrm{gal}$ in the $\mathrm{WB}$ managed treatment to $0.28 \mathrm{lb} / \mathrm{gal}$ in the SMS-based plots. These IWUE values were nearly twice those obtained with mini watermelon grown using deficit irrigation (Rouphael et al., 2008 ) and consistent with reported IWUE values obtained from other watermelon studies (Xie et al., 2010). The SMS-based irrigation system was automated and watered on-demand, with high frequency and short duration irrigation events. This may result in more water retained in the plant root zone after irrigation events (Munoz-Carpena and Dukes, 2017). In the present study, the twice-daily irrigations employed with the VegApp did not have a significantly different IWUE compared with the SMS-based system, suggesting that it may be as efficient in some seasons as more complex soil moisture-based systems. Year also significantly affected IWUE. Plants grown in 2017 had a significantly greater IWUE than in 2016 (Table $5)$. This increase in IWUE was the result of a decrease in water applied in 2017 compared with 2016. The reduction in water applied was a consequence of a shorter study period and increased rainfall in 2017, as WB and VegApp plots were not irrigated for several days following rain events in June and July.

There were no significant yearby treatment interactions or treatment effects for fruit TSS, firmness, or hollow heart. However, year significantly affected fruit TSS ( $\mathrm{F}=$ 194.3, $P \leq 0.01)$ and firmness $(\mathrm{F}=$ $6.0, P \leq 0.05$ ) (Table 6). Fruit TSS values ranged from $10.4 \%$ to $10.6 \%$ in the WB- and VegApp-treated plots, respectively. Fruit TSS values were significantly higher in 2016 (11.1\%) compared with 2017 (9.7\%). Fruit 
flesh firmness was significantly higher in 2017 (3.3 lbf) compared with fruit grown in 2016 (2.8 lbf). Hollow heart incidence was unaffected by treatment or year. Research regarding irrigation management in watermelon has

Table 5. Main effects of treatment and year for and irrigation water use efficiency (IWUE) for watermelon irrigated using smartphone vegetable irrigation-scheduling application (VegApp), water balance (WB), and soil moisture sensor (SMS) methods at Tifton, GA, in 2016 and 2017.

\begin{tabular}{lc}
\hline $\begin{array}{l}\text { Irrigation } \\
\text { treatment }\end{array}$ & IWUE $(\mathbf{l b} / \text { gal })^{\mathbf{z}}$ \\
\hline VegApp & $0.24 \mathrm{ab}^{\mathrm{y}}$ \\
SMS & $0.28 \mathrm{a}$ \\
WB & $0.20 \mathrm{~b}$ \\
Year & \\
2016 & $0.17 \mathrm{~b}$ \\
2017 & $0.31 \mathrm{a}$ \\
\hline
\end{tabular}

${ }^{\mathrm{z}} \mathrm{IWUE}=$ season irrigation volume divided by total marketable yield; $1 \mathrm{lb} / \mathrm{gal}=0.1198 \mathrm{~kg} \cdot \mathrm{L}^{-1}$.

y Values in the same column and year followed by the same letter are not significantly different at $P \leq 0.05$ according to Tukey's honest significant difference test.

Table 6. Main effects of treatment and year for total soluble solids (TSS) and pH for watermelon fruit produced using a smartphone vegetable irrigationscheduling application (VegApp), water balance (WB), and soil moisture sensor (SMS) methods at Tifton, GA, in 2016 and 2017.

\begin{tabular}{lccc}
\hline $\begin{array}{l}\text { Irrigation } \\
\text { treatment }\end{array}$ & TSS $\mathbf{( \% )}$ & Firmness $(\mathbf{l b f})^{\mathbf{z}}$ & $\begin{array}{c}\text { Hollow heart } \\
(\mathbf{0} \text { to 5 scale })^{\mathbf{y}}\end{array}$ \\
\hline WB & $10.4 \mathrm{a}^{\mathrm{x}}$ & $3.03 \mathrm{a}$ & $0.35 \mathrm{a}$ \\
SMS & $10.5 \mathrm{a}$ & $3.10 \mathrm{a}$ & $0.23 \mathrm{a}$ \\
VegApp & $10.6 \mathrm{a}$ & $3.03 \mathrm{a}$ & $0.31 \mathrm{a}$ \\
2016 & $11.1 \mathrm{a}$ & $2.8 \mathrm{~b}$ & $0.35 \mathrm{a}$ \\
2017 & $9.7 \mathrm{~b}$ & $3.3 \mathrm{a}$ & $0.23 \mathrm{a}$ \\
\hline
\end{tabular}

${ }^{\mathrm{z}} \mathrm{l} \mathrm{lbf}=4.4482 \mathrm{~N}$.

$\mathrm{y}_{0}=$ no incidence; $2=0.25-0.5$-inch cracking in center of fruit; $5=>1.5$-inch cracking in center of fruit; 1 inch $=$ $2.54 \mathrm{~cm}$.

${ }^{x}$ Values in the same column and year followed by the same letter are not significantly different at $P \leq 0.05$ according to Tukey's honest significant difference test. indicated that relatively large differences in irrigation volumes may be required to significantly affect fruit quality parameters such TSS or the occurrence and severity of hollow heart (Clark et al., 1996).

There were no significant yearby treatment interactions for foliar macronutrient concentrations, therefore main effects were analyzed. There was a significant treatment for foliar $\mathrm{N}(\mathrm{F}=14.91, P \leq$ sium $(\mathrm{K})$, cal $(\mathrm{Mg})$, or sulfur $(\mathrm{S})$ were unaffected by irrigation treatment (Table 7 ). Foliar N concentrations were significantly higher in the VegApp-treated plots than the SMS-grown plants.

Foliar P concentrations were unaffected by treatment, with concentrations ranging from $0.30 \%$ to $0.31 \%$ in VegApp-grown and WB-grown plants, respectively. Potassium concentrations ranged from $2.03 \%$ to $2.35 \%$ in SMStreated plants and WB-treated plants, respectively. Foliar $\mathrm{Ca}$ concentrations were greater than is typically reported for watermelon production among all treatments in both growing seasons, ranging from $4.33 \%$ to $4.15 \%$ but were unaffected by treatment (Bryson et al., 2014). Foliar $\mathrm{Mg}$ and $\mathrm{S}$ concentrations ranged from $0.45 \%$ to $0.50 \%$ and $0.33 \%$ to $0.36 \%$, across all treatments, respectively, and were within typical expected levels for watermelon.

Study year significantly affected foliar N, P, K, and Ca concentrations (Table 7). Foliar N concentrations increased $(\mathrm{F}=27.8, P \leq 0.01)$ from $4.04 \%$ in 2016 to $4.65 \%$ in 2017 . This may be expected because of lower volumes of applied in 2017, which may have reduced potential leaching across all treatments. Foliar $\mathrm{P}(\mathrm{F}=$ $5.76, P \leq 0.05)$ and $\mathrm{K}(\mathrm{F}=4.79, P=$ $0.06)$ concentrations also increased in 2017 compared with 2016. By contrast, foliar $\mathrm{Ca}(\mathrm{F}=5.4, P \leq 0.05)$ concentrations decreased by $0.87 \%$ in 2017 compared with 2016 . Foliar Ca concentrations were greater than are typically reported for watermelon foliage. Other research trials conducted in the vicinity of this study did not show elevated Ca levels (data not shown) and preplant soil Ca levels were typical for the region.

\section{Conclusions}

Irrigation volumes applied using the VegApp were more similar to $\mathrm{ET}_{\mathrm{c}}$ of watermelon than tomato [Solanum lycopersicum (Miller et al., 2018)]. This suggests that the $K_{c}$ and DAT model used in the VegApp may be more appropriate for drip-irrigated plasticulture-grown watermelon than tomato in southern Georgia. Although yields in the study were commercially acceptable, the VegApp did not improve yields over currently accepted management methods or the SMS-based irrigation. Our results suggest that the VegApp may not improve yields, but can reduce water

Table 7. Foliar concentrations of nitrogen $(\mathrm{N})$, phosphorus $(\mathrm{P})$, potassium $(\mathrm{K})$, calcium $(\mathrm{Ca})$, magnesium $(\mathrm{Mg})$, and sulfur (S) for watermelon irrigated using smartphone vegetable irrigation scheduling application (VegApp), water balance (WB), and soil moisture sensor (SMS) methods at Tifton, GA, in 2016 and 2017.

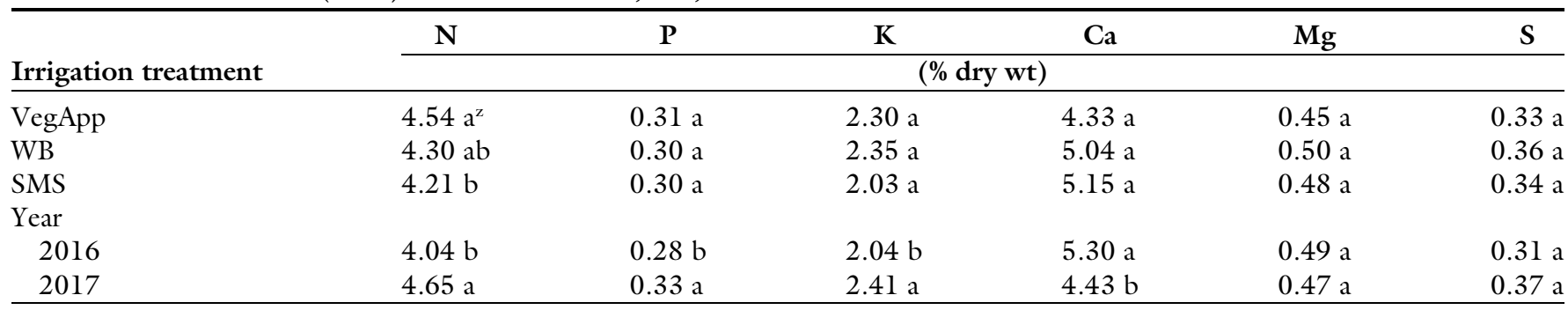

${ }^{\mathrm{z}}$ Values in the same column and year followed by the same letter are not significantly different at $P \leq 0.05$ according to Tukey's honest significant difference test. 
applications compared with current recommendations. Watermelons are a relatively drought-tolerant crop, and options to incorporate deficit irrigation into future versions of the VegApp could improve water savings even more. We conclude that the VegApp is a suitable irrigation management tool for drip-irrigated watermelons grown on plastic mulch in southern Georgia.

\section{Literature cited}

Allen, R.G., L.S. Pereira, D. Raes, and M. Smith. 1998. Crop evapotranspiration, irrigation and drainage. FAO Paper No. 56. FAO, Rome, Italy.

Bonachela, S., A.M. Gonzales, and M.D. Fernandez. 2006. Irrigation scheduling of plastic greenhouse vegetable crops based on historical weather data. Irr. Sci. 25:53-62.

Boyhan, G., D.W. Granberry, and W.T. Kelley. 2017. Commercial watermelon production handbook. Univ. Georgia Coop. Ext. Bul. 996.

Bryson, G.M., H.A. Mills, D.N. Sasseville, J.B. Jones, and A.V. Barker. 2014. Plant analysis handbook III. Micro Macro Publ., Athens, GA.

Cardenas-Lailhacar, B., M.D. Dukes, and G.L. Miller. 2010. Sensor-based automation of irrigation on bermudagrass, during dry weather conditions. J. Irr. Drain. Eng. 136:184-193.

Clark, G.A., D.N. Maynard, and C.D. Stanley. 1996. Drip-irrigation management for watermelon in a humid region. Appl. Eng. Agr. 12:335-340.

Coolong, T. 2016. Evaluation of shallow subsurface drip irrigation for the production of acorn squash. HortTechnology 26:436-443.

Coolong, T. 2017. Trial report: Watermelon variety evaluation 2017. 21 Dec. 2017. <http://www.caes.uga.edu/extensionoutreach/commodities/vegetables/trialresults/watermelon.html>.

Coolong, T., S. Surendan, and R. Warner. 2011. Evaluation of irrigation threshold and duration for tomato grown in a silt loam soil. HortTechnology 21:466-473.

Dabach, S., U. Shani, and N. Lazarovitch. 2015. Optimal tensiometer placement for high-frequency subsurface drip irrigation management in heterogeneous soils. Agr. Water Mgt. 152:91-98.

De Pascale, S., D. Costa, S. Vallone, G. Barbieri, and A. Maggio. 2011. Increasing water use efficiency in vegetable crop production: From plant to irrigation systems efficiency. HortTechnology 21: 301-308.

Dukes, M.D., E.H. Simonne, W.E., Davis D.W. Studstill, and R. Hochmuth. 2003. Effect of sensor-based high-frequency irrigation on bell pepper yield and water use. Proc. Intl. Conf. Irr. Drainage 2:665-674.

Dukes, M.D., L. Zotarelli, G.D. Liu, and E.H. Simonne. 2015. Principles and practices of irrigation management for vegetables. Univ. Florida Inst. Food Agr. Sci. Bul. AE260.

Harrison, K. 2009. Irrigation scheduling methods. Univ. Georgia Coop. Ext. Bul. 974.

Hausbeck, M.K. and K.H. Lamour. 2004. Phytophthora capsici on vegetable crops: Research progress and management challenges. Plant Dis. 12:1292-1303.

Hord, M.J. and J.B. Ristaino. 1992. Effect of the matric component of soil water potential on infection of pepper seedlings in soil infested with oospores of Phytophthora capsici. Phytopathology 82:792-798.

Horton, D. 2016. 2016 Georgia pest management handbook. Univ. Georgia Coop. Ext. Serv. Spec. Bul. 28.

Marouelli, W.A. and W.L.C. Silva. 2007. Water tension thresholds for processing tomatoes under drip irrigation in central Brazil. Irr. Sci. 25:41-48.

Migliaccio, K.L., K.T. Morgan, G. Vellidis, L. Zotarelli, C. Fraisse, B.A. Zurweller, D. Rowland, J.H. Andreis, and J.H. Crane. 2016. Smartphone apps for irrigation scheduling. Trans. Amer. Soc. Agr. Biol. Eng. 59:291-301.

Miller, G.A., H.J. Farahani, R.L. Hassell, A. Khalilian, J.W. Adelberg, and C.E. Wells. 2014. Field evaluation and performance of capacitance probes for automated drip irrigation of watermelons. Agr. Water Mgt. 131:124-134.

Miller, L., G. Vellidis, O. Mohawesh, and T. Coolong. 2018. Comparing a smartphone irrigation scheduling application with water balance and soil moisture-based irrigation methods: Part I-Plasticulturegrown tomato. Hort Technology 38:362-369.

Munoz-Carpena, R. and M.D. Dukes. 2017. Automatic irrigation based on soil moisture for vegetable crops. Univ. Florida Inst. Food Agr. Sci. Bul. 354.

Munoz-Carpena, R., M.D. Dukes, Y.C.C. $\mathrm{Li}$, and W. Klassen. 2005. Field comparison of tensiometer and granular matrix sensor automatic drip irrigation on tomato. HortTechnology 15:584-590.

Proietti, S., Y. Rouphael, G. Colla, M. Cardarelli, M. De Agazio, M. Zacchini, S. Moscatello, and A. Battistelli. 2008. Fruit quality of mini-watermelon as affected by grafting and irrigation regimes. J. Sci. Food Agr. 88:1107-1114.

Rouphael, Y., M. Cardarelli, G. Colla, and E. Rea. 2008. Yield, mineral composition, water relations, and water use efficiency of grafted mini-watermelon plants under deficit irrigation. HortScience 43:730-736.

Shukla, S., N.K. Shrestha, F.H. Jaber, S. Srivastava, T.A. Obreza, and B.J. Boman. 2013. Evapotranspiration and crop coefficients for watermelon grown under plastic mulched conditions in sub-tropical Florida. Agr. Water Mgt. 132:1-9.

Smajstrla, A.G. and S.J. Locascio. 1990. Irrigation scheduling of drip-irrigated tomato using tensiometers and pan evaporation. Proc. Florida State Hort. Soc. 103:88-91.

University of Florida. 2012. Smart irrigation applications. 10 Jan. 2016. <www. smartirrigationapps.org $>$.

U.S. Department of Agriculture. 2006. United States standards for grades of watermelons. U.S. Dept. Agr., Washington, DC.

Vellidis, G., M. Tucker, C. Perry, C. Kvien, and C. Bednarz. 2008. A real-time wireless smart sensor array for scheduling irrigation. Comput. Electron. Agr. 61:44-50.

Vellidis, G., M. Tucker, C. Perry, D. Reckford, C. Butts, H. Henry, V. Liakos, W.R. Hill, and W. Edwards. 2013. A soil moisture sensor-based variable rate irrigation scheduling system. 9th European Conf. Precision Agr., Catalonia, Spain, 711 July 2013. p. 713-720.

Vellidis, G., V. Liakos, C. Perry, P. Roberts, M. Tucker, and E. Barnes. 2015. Field evaluation of a smartphone app for scheduling irrigation in cotton. Proc. 2015 Beltwide Cotton Conf., San Antonio, TX, 6 Jan. 2015. p. 913-918.

Wolfe, K. and K. Stubbs. 2016. 2015 Georgia farm gate value report. Univ. Georgia Coop. Ext. Bul. AR-16-01.

Xie, Z., Y. Wang, G. Cheng, S. Malhi, C. Vera, Z. Guo, and Y. Zhang. 2010. Particlesize effects on soil temperature, evaporation, water use efficiency, and watermelon yield mulched with gravel and sand in semiarid Loess Plateau of northwest China. Agr. Water Mgt. 97:917-923.

Zitter, T.A., D.L. Hopkins, and C.E. Thomas. 1996. Compendium of cucurbit diseases. APS Press, St. Paul, MN.

Zotarelli, L., M.D. Dukes, J.M.S. Scholberg, R. Munoz-Carpena, and J. Icerman. 2009. Tomato nitrogen accumulation and fertilizer use efficiency on a sandy soil, as affected by nitrogen rate and irrigation scheduling. Agr. Water Mgt. 96:1247-1258. 